Colyn, R. B., A. Campbell, and H. A. Smit-Robinson. 2020. The use of a camera trap and acoustic survey design to ascertain the vocalization and breeding status of the highly elusive White-winged Flufftail, Sarothrura ayresi. Avian Conservation and Ecology 15(2):12. https://doi. org/10.5751/ACE-01681-150212

Copyright (C) 2020 by the author(s). Published here under license by the Resilience Alliance.

Research Paper

\title{
The use of a camera trap and acoustic survey design to ascertain the vocalization and breeding status of the highly elusive White-winged Flufftail, Sarothrura ayresi
}

\author{
Robin B. Colyn ${ }^{1,2}$, Alastair Campbell ${ }^{3}$ and Hanneline A. Smit-Robinson ${ }^{2,4,5}$ \\ ${ }^{1}$ FitzPatrick Institute of African Ornithology, DST-NRF Centre of Excellence, University of Cape Town, South Africa, \\ ${ }^{2}$ BirdLife South Africa, ${ }^{3}$ Southern African Institute of Ecologists and Environmental Scientists, South Africa, ${ }^{4}$ Applied \\ Behavioural Ecological \& Ecosystem Research Unit (ABEERU), UNISA, South Africa, ${ }^{5}$ School of Animal, Plant and \\ Environmental Sciences, University of Witwatersrand, South Africa
}

\begin{abstract}
The critically endangered White-winged Flufftail, Sarothrura ayresi, was first described in 1877 and yet significant data deficiencies in the vocalization and breeding status of this species still exist. This species currently faces a high extinction risk, largely due to extensive habitat loss, and respective data deficiencies have hampered conservation efforts. The species' elusive behavior, cryptic coloration, and preference for densely vegetated wetland habitats has resulted in traditional survey methods being ineffective in addressing these data deficiencies. Our study employed a survey design combining camera traps and passive acoustic monitoring to address significant and critical data deficiencies related to the breeding and vocalization characterization of the species. This method successfully established that this species does not breed exclusively in the Ethiopian Highlands and that an additional breeding population exists in South Africa. The combined use of camera and acoustic data allowed for the confirmation of the species vocalizations and allows for the refuting of calls previously attributed to the species. Additionally, this method allowed for the assessment of activity patterns relative to demographics (age and gender). With the call confirmed, and breeding range redefined, we recommend the use of passive acoustic monitoring as a rapid means of noninvasively identifying the presence of this highly elusive species at other sites across its range in order to bolster conservation efforts for this critically endangered species. Additionally, our results confirm that passive acoustic monitoring can provide more robust datasets and assess a range of ecological facets noninvasively, while yielding presence records more rapidly than alternate methods such as call-broadcasts, walked transects, and flushing.
\end{abstract}

\section{L'utilisation d'un modèle à piège photographique et à étude acoustique pour s'assurer du statut de vocalisation et de reproduction du très discret râle à miroir, Sarothrura ayresi}

RÉSUMÉ. Gravement menacé, le râle à miroir (Sarothrura ayresi) fut décrit pour la première fois en 1877. Il subsiste pourtant des lacunes significatives de données concernant la vocalisation et la reproduction de cette espèce. Cet oiseau est actuellement fortement menacé d'extinction, en grande partie en raison d'une perte importante de son habitat. De plus, des carences de données adéquates ont entravé les efforts de conservation. Le comportement discret de cette espèce, sa coloration mystérieuse et son goût pour les habitats humides à végétation dense ont toujours nui à l'efficacité des méthodes d'observation classiques pour compenser ces manques de données. Notre étude a employé un modèle d'observation avec pièges photographiques et surveillance acoustique passive pour gérer les lacunes critiques et importantes de données concernant la caractérisation de la reproduction et de la vocalisation de cette espèce. Cette méthode a permis d'établir que cet oiseau ne se reproduit pas exclusivement sur les hauts plateaux d'Éthiopie et que d'autres populations se reproduisent en Afrique du Sud. L'utilisation combinée des données photographiques et acoustiques a permis de confirmer les vocalisations de l'espèce et de réfuter les cris précédemment attribués à cet oiseau. En outre, cette méthode a permis d'évaluer les habitudes d'activité en termes démographiques (selon l'âge et le sexe). Maintenant que la nature du cri a été confirmée et les territoires de reproduction redéfinis, nous recommandons l'utilisation d'une surveillance acoustique passive comme moyen rapide d'identifier de manière non-invasive la présence de cette espèce très discrète sur d'autres sites de son territoire afin de favoriser les efforts de conservation de cet oiseau fortement menacé. Nos résultats confirment également que la surveillance acoustique passive peut produire des jeux de données plus solides et évaluer une série de facettes écologiques de manière non-invasive, tout en produisant des dossiers de présence plus rapidement que les méthodes alternatives comme les diffusions de cris, les analyses réalisées à pied et la méthode par élimination.

Key Words: acoustic monitoring; breeding ecology; camera trapping; rallid; wetland; vocalization 


\section{INTRODUCTION}

Wetlands and associated waterbird populations are globally in decline, with recent assessments suggesting that as many as $40 \%$ have declining population trends and $4 \%$ are already extinct (Kirby et al. 2008, Ramsar Convention on Wetlands 2018). Wetland rallids are facing similar threats with $46 \%$ of species globally in current decline (BirdLife International 2018). Many wetland rallid species, particularly those inhabiting dense marsh habitats, are highly elusive and notoriously difficult to study (Taylor and van Perlo 1998, Allan et al. 2006, Davies et al. 2015, Colyn et al. 2017, 2019). Subsequently, 33\% of wetland rallid species have significant data deficiencies related to population status, distribution, and facets of ecology (BirdLife International 2018, Colyn et al. 2020).

The White-winged Flufftail Sarothrura ayresi is one of Africa's most enigmatic and threatened rallid species (Taylor and van Perlo 1998, Colyn et al. 2019, 2020). Although the Sarothruridae family (flufftails, wood rails, and forest rails) is considered by some, but not all, taxonomic bird lists as a sister family to the larger Rallidae (rail) family based on molecular analyses (Garcia et al. 2014), many species within the respective families remain functionally similar (Taylor and van Perlo 1998) and hereafter colloquially referred to as rallids. As a result of a constrained geographic range and a declining population (Evans et al. 2015), White-winged Flufftail is currently listed as critically endangered according to the IUCN Red List Criteria (BirdLife International 2018). Because of its rarity and secretive nature, there are currently significant data deficiencies related to the species population size, trend, distribution, ecology, and behavior (Evans et al. 2015). This species inhabits shallowly flooded and densely vegetated palustrine wetland habitats, particularly sedge meadows and mixed-sedge vegetation units (Taylor 1994, Davies et al. 2015, Colyn et al. 2019, 2020). Although historical records were obtained from Phragmites dominant vegetation (Taylor 1994), recent studies of habitat use noted a complete absence of the species in pure stands of Phragmites vegetation (Colyn et al. 2019). Drivers of local occupancy include high basal and canopy cover (Colyn et al. 2019) and primary threats to habitat suitability include overgrazing, harvesting of sedge, trampling by livestock, and habitat transformation through anthropogenic developments (Evans et al. 2015, Colyn et al. 2019, 2020). The species is only recorded with any recent $(>2000)$ regularity from two sites in the Ethiopian Highlands and one site within the highland region of South Africa (Evans et al. 2015, Colyn et al. 2019, 2020).

It is believed that this species breeds exclusively in the Ethiopian Highlands and migrates to the nonbreeding austral summer range in South Africa (Taylor 2005). Although two historic (1982, 1983) sightings have alluded to potential breeding presence in South Africa, neither produced any acceptable evidence thereof (Taylor 1994). The only reputable breeding sites, namely Berga, Weserbi, and Bilacha Wetlands in Ethiopia (Taylor et al. 2004), are being rapidly transformed and fragmented and significant declines ( 95\%) in breeding habitat have been recorded (Colyn et al. 2020). Identifying and securing alternate breeding sites is imperative for the persistence of this Critically Endangered species (Colyn et al. 2020). A recent study in South Africa documented visual displays between male and female White-winged Flufftail, as well as general signs of territoriality (Colyn et al. 2019). Although some forms of territorial behavior have been documented for other rallid species in nonbreeding ranges (Taylor 1987), these sightings in South Africa require further investigation to confirm their status.

Although auditory surveys are often utilized as an effective means of surveying elusive wetland species (Bogner and Baldassarre 2002, Lor and Malecki 2002, Conway and Gibbs 2005), their use is currently impeded by discrepancies related to the true status of this species call (Allan et al. 2006, Davies et al. 2015). Typically, species vocalizations are verified through focused recording by means of acoustic equipment, with the target species in sight (Hill 2011, 2018, Baylis et al. 2015, Norambuena and Muñoz-Pedreroz 2017). However, the secretive and elusive behavior of this species has resulted in this method being ineffectual at studying vocalizations (Allan et al. 2006, Davies et al. 2015). Taylor (1994) recorded three different vocalizations that were attributed to White-winged Flufftail (Taylor 2005), but none were recorded with birds in view. Additionally, two of these calls are highly comparable to vocalizations made by the sympatric Red-chested Flufftail Sarothrura rufa, while the third is highly comparable to a courtship call made by Grey Crowned Crane Balearica regulorum (Taylor 1994). Although multiple surveys have subsequently been conducted to record this species' call, none have been successful and the vocal repertoire of the species remains ambiguous (Allan et al. 2006, Davies et al. 2015). A survey conducted at their breeding grounds in Ethiopia found active nests, but was unable to record any vocalizations and concluded that either the species was silent, or the calls were possibly inconspicuous (Allan et al. 2006). Given the current lack of data and difficulty in studying White-winged Flufftail, verifying and correctly characterizing the species' call would directly benefit conservation efforts underway (Davies et al. 2015), as well as fill a critical data deficiency.

This species' small body size ( $\sim 30 \mathrm{~g})$, elusive behavior, cryptic coloration, preference for dense aquatic wetland vegetation, lack of auditory cues, low density, and fragmented distribution has resulted in this species being significantly difficult to study (Taylor 1994, Allan et al. 2006, Davies et al. 2015, Colyn et al. 2019). Traditionally, the only effective method of surveying the species involved walked transects and/or rope dragging (Davies et al. 2015). This invasive form of sampling, however, had limited success in yielding presence records (Davies et al. 2015), while also raising concerns of the associated impact of trampling and flushing on the species and its' preferred habitat (Davies et al. 2015, Colyn et al. 2017, 2019). However, recent studies have successfully utilized camera traps, a noninvasive form of remote photography, as a method of surveying small bodied rallid species (Colyn et al. 2017, Znidersic 2017, Hand et al. 2019, Znidersic et al. 2019), including White-winged Flufftail (Colyn et al. 2019). Our study aimed to determine, first, if a camera trap survey could confirm the breeding status of White-winged Flufftail in South Africa. Second, we wanted to ascertain if a survey design incorporating and combining camera traps and acoustic recorders could elucidate and confirm the vocal repertoire of White-winged Flufftail, and if call-response surveys using playbacks of vocalizations recorded in our study in South Africa could elicit presence records of White-winged Flufftail in Ethiopia. This would allow us to assess if calls recorded at the northern (Ethiopia) and southern (South Africa) localities were comparable. Third, we wanted to determine if further behavioral 
inferences and interactions could be drawn with regard to demographics and peak activity patterns.

\section{METHODS}

\section{Study sites}

The study took place within the two core regions noted to host White-winged Flufftail globally, namely South Africa and Ethiopia (Evans et al. 2015). The primary study site was located at Middelpunt Wetland in the Mpumalanga Province of South Africa (-25.52, 30.12), while the secondary site was located within Berga Wetland $(9.27,38.39)$ in the Oromia Region of Ethiopia (Fig. 1). Both sites are characterized by palustrine wetland catchments within highland grassland ecosystems and have yielded the largest number of consistent presence records for White-winged Flufftail (Allan et al. 2006, Davies et al. 2015, Colyn et al. 2019, 2020). Berga Wetland is noted as the primary breeding site for the species (Taylor and van Perlo 1998, Allan et al. 2006, Colyn et al. 2020), while Middelpunt Wetland has been a focal research area for the species in the austral summer range in South Africa (Davies et al. 2015, Colyn et al. 2019).

Fig. 1. The locality of the study sites in South Africa (a \& d) and Ethiopia ( $\mathrm{a} \& \mathrm{~b}$ ). The survey design utilized at the primary study site in South Africa included 16 camera traps and an acoustic recorder placed in suitable wetland habitat (c).

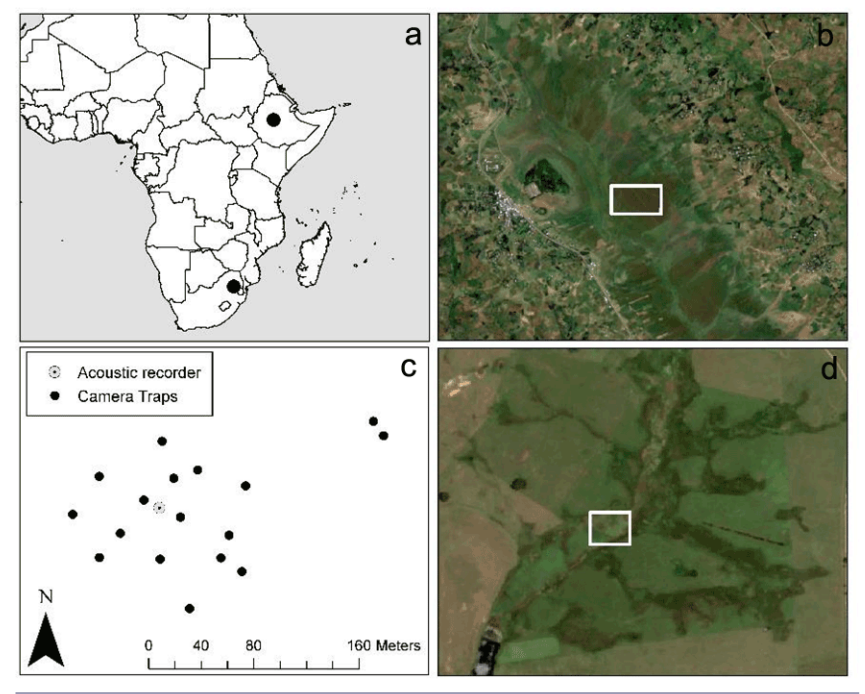

\section{Survey design}

Studies aimed at optimizing camera trap survey design for smallbodied rallid (Colyn et al. 2017) and flufftail (Sarothrura) species (Colyn et al. 2019) have been conducted in recent years. These studies optimized camera trap placement properties, including camera height, focal distance, and angle (Colyn et al. 2017), as well as camera spacing (Colyn et al. 2019) for rallids within wetland habitats. Our study adopted these survey design parameters, which included a camera placement height of $\sim 30$ $40 \mathrm{~cm}$ and camera angle of $20-30^{\circ}$ (Colyn et al. 2017). Given the objective of the study was to collect fine-scale data related to species behavior and activity, i.e., vocalizations, territoriality, and breeding, the camera grid utilized included an intensive sampling regime of 16 camera stations ( $\mathrm{Ltl}$ Acorn 6540MC) and one central acoustic station (SM4 Acoustic Recorder) within a 2-ha section of suitable wetland habitat in order to obtain direct correlations between any vocalization recordings and images captured. Subsequently, the section of Middelpunt Wetland chosen to place cameras within primarily comprised sedge dominant and mixed sedge vegetation habitats, but included marginal sections of dominant Typha and Phragmites vegetation.

\section{Breeding confirmation in South Africa (Middelpunt Wetland)}

Camera spacing as informed by Colyn et al. (2019) was based on the average home range size of the sympatric Red-chested Flufftail (0.10-0.45 ha; Taylor 1994). Maintaining camera spacing at, or larger than, the average diameter of the focal species' territory meets the assumption of independence and prevents spatial auto-correlation (Rovero et al. 2013). Given the need to correlate images taken from camera traps with vocalizations recorded on the acoustic recorder, we spaced cameras a minimum of 30 meters apart in suitable habitat surrounding a central acoustic device (Fig. 1c). This allowed for maximum camera trap coverage surrounding the acoustic recorder, while maintaining the assumption of independence as the spacing was at, or larger than, the average home range diameter $(30 \mathrm{~m})$ of Red-chested Flufftail (Taylor 1994). Sections of suitable habitat that were targeted for placement were based on the micro-habitat preferences noted to influence site occupancy, namely shallowly flooded $(\leq 15 \mathrm{~cm})$ areas with high basal $(\geq 70 \%)$ and canopy $(\geq$ $40 \%$ ) cover in sedge dominant or mixed sedge vegetation units (Colyn et al. 2019). Vegetation cropping directly in front of camera traps was avoided wherever possible because this was highlighted as potentially negatively influencing local site suitability and therefore detection probability as well (Colyn et al. 2019). In order to maximize the potential of recording Whitewinged Flufftail, we commenced our survey early in the austral summer season (Colyn et al. 2019) and surveyed for 125 consecutive days (December 2017 to April 2018).

\section{Vocalization confirmation}

The acoustic recorder (SM4 acoustic recorder) was placed centrally within the camera trap grid and suitable habitat (Browning et al. 2017, Colyn et al. 2019). Because of the uncertainty related to the species' call, the acoustic recorder was programmed to include no high pass filter, i.e., better for low frequency calls, and a sample rate of $44100 \mathrm{~Hz}$, while all other settings were left on default. The sampling schedule was set to record for four hours over sunrise (04:00-08:00) and sunset (16:00-20:00), which are periods of peak activity for the species (Taylor 1994, Colyn et al. 2019). The acoustic recorder sampled for 42 consecutive days over the peak summer season (December 2017 to end January 2018).

The primary objective of the Ethiopian field work was to further validate the vocalizations recorded in South Africa and attempt to compare vocalizations recorded between the two extremities of the species' range, i.e. South Africa and Ethiopia. As such, an alternate rapid survey method was employed, namely callbroadcast surveys. Call-broadcast or call-response surveys are noted as an efficient method of monitoring avian species and have been extensively used on marsh bird communities (Bogner and Baldassarre 2002, Lor and Malecki 2002, Turcotte and 
Desrochers 2002, Conway and Gibbs 2005, Brandes 2008, Conway 2011). Studies have noted that call-broadcast surveys are effective for numerous elusive wetland species (Bogner and Baldassarre 2002, Lor and Malecki 2002, Conway and Gibbs 2005) and particularly during the breeding season while birds are initiating nesting (Bogner and Baldassarre 2002). However, callbroadcast surveys have also proved inefficient for certain species, particularly nonrallids (Conway and Gibbs 2005), and to accommodate for this it is recommended that surveys incorporate both passive listening and active call-broadcasts (Conway and Gibbs 2005). Subsequently, we used a combination of acoustic recording, i.e., passive listening, and call-broadcast surveys at a 5-ha study site (Colyn et al. 2020) within the Berga Wetland catchment in Ethiopia, which is noted as the largest known breeding site for the species globally (Taylor and van Perlo 1998, Taylor et al. 2004, Colyn et al. 2020).

Call-broadcasts were utilized for a maximum of one minute during a five-minute survey. These surveys were repeated for six iterations, i.e., 30 minutes total, following sunrise ( 06:00). Areas that yielded responses were then searched using traditional walked line transect methodology (Bibby et al. 1998, Fletcher et al. 2000) with only two observers to keep any potential impact to a minimum. Observers walked parallel to one another in a similar fashion to rope dragging surveys (Bibby et al. 1998, Davies et al. 2015), which is noted as a widely utilized and effective method of surveying rallids (Mendelsohn et al. 1983, Fletcher et al. 2000, Allan et al. 2006, Davies et al. 2015). Call-broadcast surveys were used in our study in an attempt to elicit responses and obtain confirmed presence records of White-winged Flufftail at breeding grounds in Ethiopia. Calls used during broadcasts or playbacks were the only vocalizations available, namely those recorded in the austral summer range of South Africa during this study. Transects recorded all species noted in the areas searched where initial call responses were heard, as well as the density of birds observed, sex (if possible), and any behavior noted (flushed, breeding, nesting, etc.). The same data were recorded for any incidental sightings of birds observed coming to the callbroadcast station to investigate, i.e., territorial behavior, the origin of the call.

Passive acoustic monitoring was conducted from 19 to 22 July 2018 for three hours over sunrise and sunset. Call-broadcast surveys were conducted at dusk and dawn for 30-minute periods.

\section{Data analysis}

All camera trap footage was collated using the R ( $R$ Development Core Team 2017) package camtrapR (Niedballa et al. 2016). This package provides an efficient data management system for camera trap images that includes image organization, image categorization, data extraction, and generating results and data exports (Niedballa et al. 2016). Camera trap images related to all ground foraging avian species (rallids, snipe, etc.) were recorded, as well as medium-to-large mammalian species (Colyn et al. 2019). Sightings of small mammals (rodents) were not collated for the purposes of this study. Two data subsets were created from this master dataset including all species, namely one with exclusively White-winged Flufftail sightings and a second with all other rallid species. The White-winged Flufftail dataset was then filtered using the dataset of other rallid species to only include sightings of White-winged Flufftail that had no other rallid activity on all cameras for a 10 minute interval surrounding the respective sighting. This filtered dataset therefore represented sightings within 10 minute periods in which White-winged Flufftail was the only rallid recorded across the camera trap grid. This dataset was then further filtered to highlight those sightings in which any potential territorial behavior was noted, including the display of white secondaries during wing-flapping (Colyn et al. 2019), the intentional display of white secondary patches while wings are folded in (Colyn et al. 2019), birds climbing up on vegetation to gain height, which has been noted during territorial vocalizations in other flufftail species (Taylor 1994), and any other signs pertaining to vocalizing or territoriality (wing flapping or spreading, alighting on fallen reeds, visible throat and chest bulging). The date and time stamps from this final dataset were then assessed against the acoustic data recorded during this study.

All acoustic data were processed and assessed using software package Raven Pro version 1.5 (http://ravensoundsoftware.com/). The initial assessment of acoustic data included clipping the acoustic sound clips to the final refined White-winged Flufftail camera trap dataset. This resulted in 10-minute sound clips that were temporally synchronized (via date/time stamps) with observed periods of White-winged Flufftail territorial activity from camera trap footage. Given the filtering conducted on camera trap footage, these periods of White-winged Flufftail activity also simultaneously represented periods of no noted presence of other rallid species across respective camera data. Because of the lack of confirmed acoustic signatures for Whitewinged Flufftail, we were unable to use automatic recognizers for processing acoustic data (Sidie-Slettedahl et al. 2015, Znidersic et al. 2019). Therefore, all 10-minute clips identified to overlap with White-winged Flufftail activity from camera traps were manually assessed. Assessing these clips included aurally and visually (spectrograms) reviewing clips in Raven Pro 1.5 (SidieSlettedahl et al. 2015). The review process included isolating any bird calls heard for identification to species-level using existing acoustic databases, Roberts VII Multimedia Birds of Southern Africa (Gibbon 2012), and Xeno-canto (https://www.xeno-canto. org/). Data recorded during the review included clip ID no, call time start, call time end, species ID, and whether multiple species calls overlapped in the given clip. The R package seewave (Sueur et al. 2019) was used to create spectrograms of all rallid species identified in our study. Any calls identified in 10-minute acoustic clips that did not match known signatures of rallid species expected to occur within the given region and/or confirmed in our study were isolated for further analysis. These calls were assessed and verified by creating and analyzing spectrograms, as well as evaluating acoustic similarity and measuring acoustic parameters in $\mathrm{R}$ package seewave (Sueur et al. 2019). Spectrograms were created using the sampling frequency at which data was recorded $(44100 \mathrm{~Hz})$, a window frame length of 512, and window type was set to Hanning (default). The amplitude scale $(\mathrm{dB})$ used in our spectrograms is the default $10 \log 10$ (power ratio) scale created by the seewave package.

Kernel density estimation (KDE), a nonparametric method of evaluating the density function (Rideout and Linkie 2009), was utilized to assess activity patterns in software $\mathrm{R}$ ( $\mathrm{R}$ Development Core Team 2017). Activity pattern analysis was conducted to estimate peaks in activity noted from both camera trap (foraging, breeding) and acoustic (vocalizations) data. The $\mathrm{R}$ package 
overlap (Meredith and Ridout 2017) was used to assess the measure of overlap between peaks in recorded vocalizations and that of activity noted from camera trap data. Two temporal periods of assessment were used, namely a conventional 24-hour/ daily cycle and a seasonal cycle (December to April; Meredith and Ridout 2017). Because of the influence of sample size on the performance of estimators of coefficient of overlapping, sample sizes smaller than 50 were allocated the "Dhat 1" estimator in the $\mathrm{R}$ package overlap (Linkie and Rideout 2011, Meredith and Ridout 2017). Consecutive sightings of the same species at the same survey point were deemed independent when separated by a 30-minute interval (Colyn et al. 2019).

\section{RESULTS}

Our study yielded a total of 2000 camera days (December to April) and 336 acoustic hours (December to February) of sampling at Middelpunt Wetland. Camera traps recorded 34,422 images across four rallid species, of which 3726 were deemed independent sightings, i.e., separated by 30 min intervals (Colyn et al. 2019). This included 563 images of White-winged Flufftail, of which 128 were deemed independent sightings.

\section{Breeding in South Africa (Middelpunt Wetland)}

Significantly, during this period of peak activity our study recorded four confirmed breeding records for the species. This finding constitutes the first confirmed breeding records for the species in its austral summer range within the Southern Hemisphere. The first breeding record in early summer (23 December) comprised two juvenile birds that had not yet undergone postjuvenile molt (Taylor and van Perlo 1998), followed by three records of adults with very young $(<1$ week old; Taylor and van Perlo 1998, Taylor et al. 2004) chicks during early January (7-14 January), late January (24 January), and early February (2 February; Fig. 2). A second, shorter period of lower seasonal activity was recorded during early autumn (i.e., 88-113 survey days) and largely comprised juvenile birds (Figs. 3 and 4).

Fig. 2. Varied age classes of White-winged Flufftail (Sarothrura ayresi) recorded during our study: (a) Adult female with three young chicks, (b) juvenile/immature male with partial chestnut coloration on neck and chest, (c) juvenile female with overall dark plumage, white spots on upperparts, white throat, and white terminal band on tail.

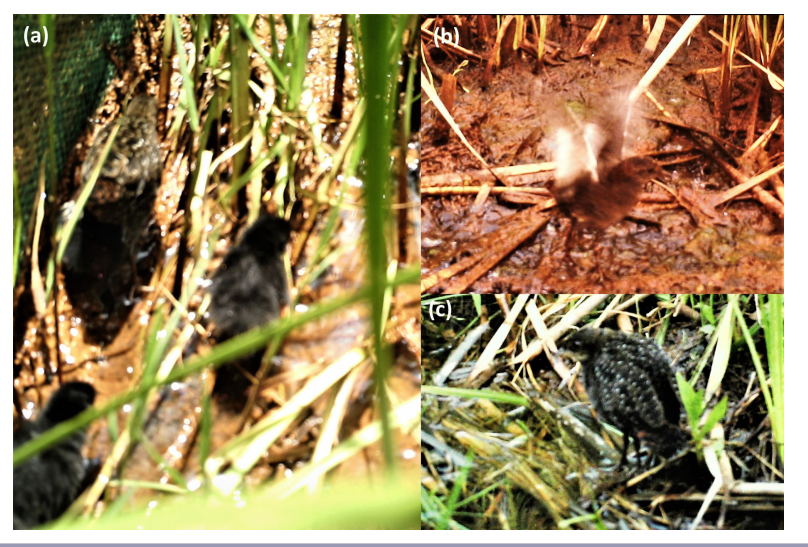

Fig. 3. Peak periods of White-winged Flufftail (Sarothrura ayresi) activity recorded from camera trap and acoustic data over daily (right) and seasonal (left) cycles.
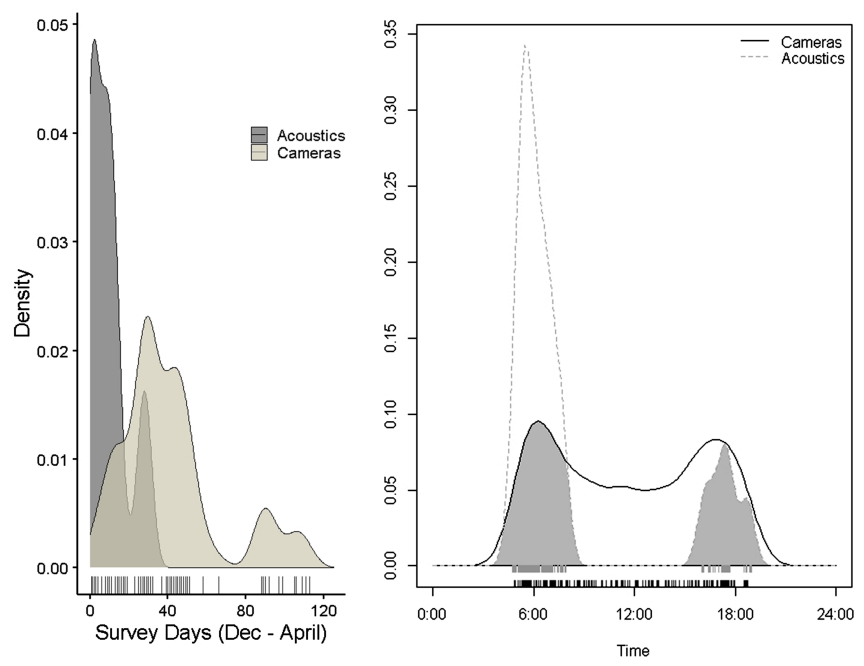

Fig. 4. Daily (above) and seasonal (below) peak activity pattern results for White-winged Flufftail (Sarothrura ayresi), grouped by sex (left) and age class (right).
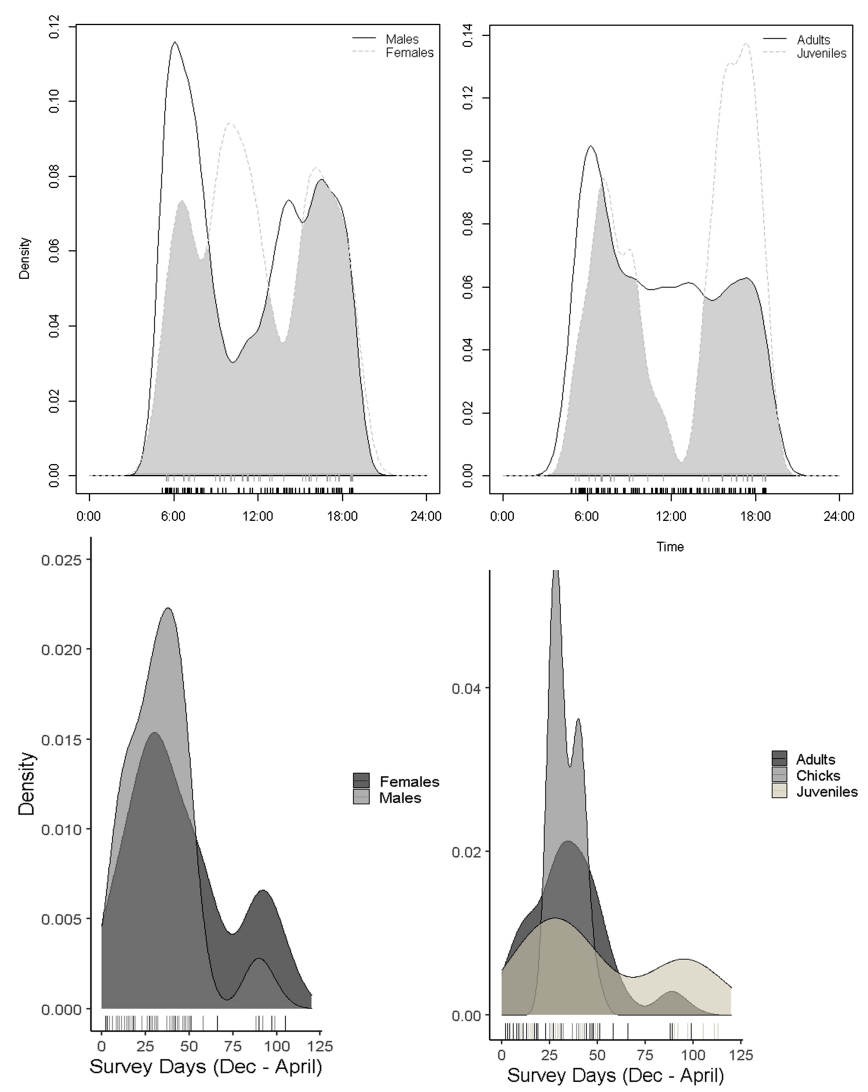


\section{Vocalization confirmation}

The White-winged Flufftail camera trap dataset filtered to only include sightings during which no other rallid species were observed on cameras for 10 minutes prior or after a sighting, incorporated 55 independent records of presence. Additionally, when this dataset was further filtered to include sightings displaying territorial behavior (Taylor 1994, Colyn et al. 2019), 25 records remained. Evaluation of acoustic data at the synchronized (camera-acoustic) time of the 25 records resulted in the detection of the same unattributed, i.e., unknown, vocalization at $17(68 \%)$ of the White-winged Flufftail sightings.

The unattributed vocalizations comprised similar metallic staccato "chit" notes used in three, four, and five note strophes (Fig. 5, Appendix 1), where a strophe is defined as the collection of single notes to form the call (Catchpole and Slater 2008). Typically, the first two chits in any given strophe were $\sim 0.4$ seconds apart, with subsequent notes rising in tempo to conclusion (Fig. 5). Acoustic characteristics of individual chit notes encompassed a frequency range of 294 (low avg.) and 4800 (high avg.) hertz over $\sim 0.05$ seconds. Strophes were often repeated in rapid succession (Appendix 1) and included short ( $\sim 0.5$ to 1 minute) intervals separating longer concurrent sequences of calling. Varied sequences of chits and strophes were often utilized over an average period of 6-8 minutes, with the longest sequence lasting 24 minutes. The acoustic database generated across the entire study yielded the identification of 198 sequences of chit vocalizations. The majority ( $98 \%$ ) of calls exclusively included the use of chit calls in various sequences, particularly the three, four, and five note strophes (Fig. 5, Appendix 1). However, four sequences $(2 \%)$ included a single chit proceeded by a rapid trill lasting $\sim 1$ second (Fig. 6). All sequences that included the trill call involved extended vocalizations between two or more conspecific birds lasting between 9 and 24 minutes, possibly indicating that this call was used as an aggression/warning or alarm call as is documented in other rallid species (Taylor and van Perlo 1998).

In Ethiopia, passive acoustic recording and active call-broadcast surveys yielded 33 recordings of calls matching that which was recorded in South Africa. Call-broadcast surveys using the vocalizations recorded in South Africa yielded 13 direct responses. Interestingly, the majority ( $>70 \%$ ) of call sequences utilized by White-winged Flufftail in South Africa were four and five note calls (Fig. 5), while in Ethiopia the majority (>90\%) recorded were three note calls. Passive recording yielded the first detection within 15 minutes, compared to that of 25 minutes with callbroadcast surveys. The only rallid species encountered on walked transects at areas of response and further throughout the study site was White-winged Flufftail. Walked transects yielded 15 sightings of White-winged Flufftail within shallowly flooded sedge habitats, which included the identification of six active nest sites. Passive recording did however record Rouget's Rail Rougetius rougetii, a species endemic to Ethiopia and Eritrea, which were sighted along deeper and more densely vegetated drainage lines on the periphery of the sedge meadow being surveyed.

Vocalizations recorded in South Africa and Ethiopia were acoustically compared to other rallid and nonrallid species recorded within respective study sites. In South Africa, the calls recorded for White-winged Flufftail were acoustically unique
Fig. 5. Spectrograms of (a) the single "chit" note, as well as the (b) three, (c) four, and (d) five note sequences of staccato chit vocalizations recorded for White-winged Flufftail (Sarothrura ayresi). Amplitude (dB) is displayed as the default seewave 10 $\log 10$ (power ratio) scale.
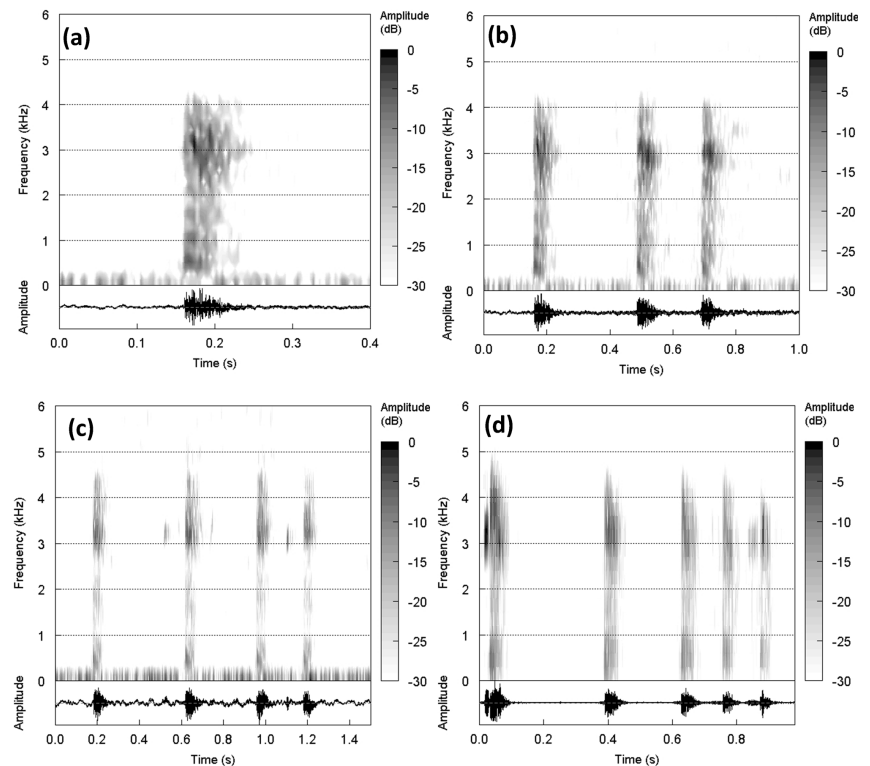

Fig. 6. Although the use of various combinations of "chit" calls were the dominant vocalization recorded for White-winged Flufftail (Sarothrura ayresi), this spectrogram displays one of four sequences of a single chit (a) followed by a rapid trill (b) that were recorded. Amplitude (dB) is displayed as the default seewave $10 \log 10$ (power ratio) scale.

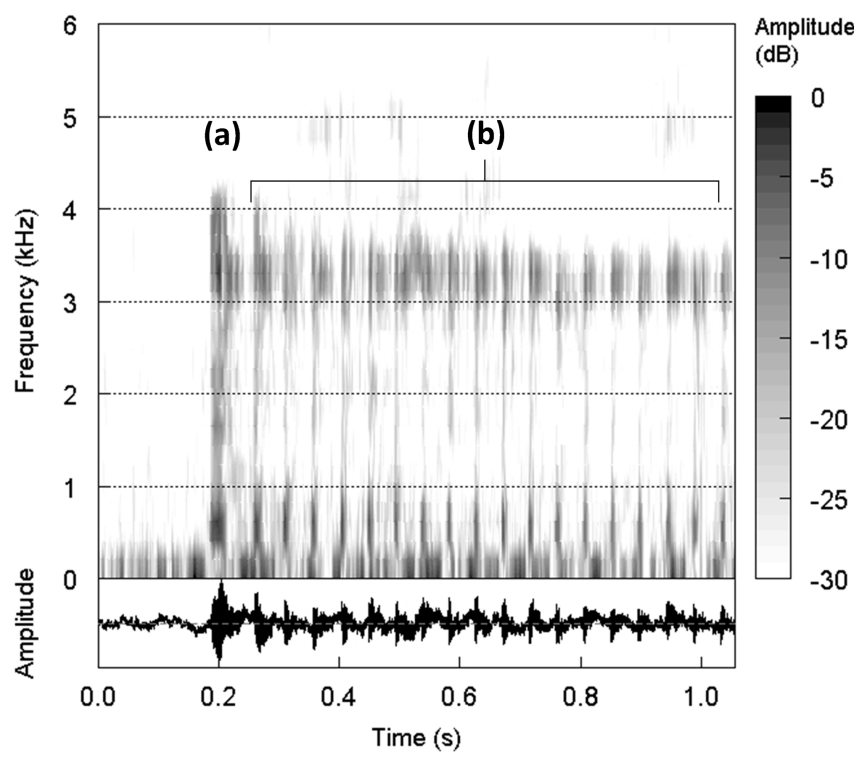


when compared to the other three rallid species identified over the study period (Dec-April), namely Red-chested Flufftail, Black Crake Amaurornis flavirostra, and African Rail Rallus caerulescens (Appendix 2). Comparative analysis was not restricted to dominant calls of other rallid species, but included all variations identified within our study. Similarly, vocalizations recorded in Ethiopia were compared to the only other rallid recorded at that study site, namely Rouget's Rail, and were acoustically unique (Appendix 2). Furthermore, comparative analysis of White-winged Flufftail calls with that of all other flufftail (Sarothrura) species across Africa (Appendix 3) yielded the same results, indicating that White-winged Flufftail vocalizations recorded in our study were acoustically unique and certainly distinguishable from other sympatric rallid species (Appendices 2 and 3).

Acoustically, White-winged Flufftail calls recorded in South Africa and Ethiopia were the same, with individual chits encompassing a frequency range of $290 \mathrm{~Hz}$ (avg. low) and 4800 $\mathrm{Hz}$ (avg. high), occurring over a duration of $\sim 0.05$ seconds. Calls were easily masked by ambient environmental sounds, particularly other bird calls. In numerous instances on acoustic recordings, White-winged Flufftails would seemingly stop vocalizing once another rallid commenced vocalizing nearby. These disturbances or abrupt halts in White-winged Flufftail vocalizations were more evident when crake and rail species started vocalizing, compared to the commencement of Redchested Flufftail vocalizations. Both passive listening in the field (Ethiopia) and acoustic signatures (dB) from recordings in South Africa and Ethiopia confirmed that the vocalizations were not conspicuously audible, were easily drowned out by other bird song and environmental noise, and would potentially not travel far. A comparative analysis of calls detected from the acoustic recorder and that recorded by passive listening at Berga Wetland (Ethiopia) displayed that calls beyond $\sim 80 \mathrm{~m}$ were not recorded/audible by passive listening in the field. Berga, however, had very little other rallid calls and ambient noise overlapping the vocalization periods of White-winged Flufftail. In South Africa, where multiple rallid species and individuals within species were vocalizing over the same periods, this constraint on audibility could be further exacerbated.

\section{Activity patterns}

Vocalization activity was greatest at dawn through to early morning (i.e., 04:45 to 08:00), with lower vocalization activity recorded from late afternoon through to dusk (16:30 to 19:00; Fig. 3). Similarly, camera trap data displayed distinct peaks in activity over dawn and dusk, with a reduction in activity over midday and no noted activity across nocturnal hours (Fig. 3). The overall overlap coefficient (Dhat4) between camera trap and acoustic data was 0.52 , but when camera trap data was truncated to the temporal periods of acoustic sampling (i.e., 04:00 to 08:00, 16:00 to 20:00), the resultant overlap coefficient was 0.9 . Seasonal activity pattern analysis of camera trap and acoustic data revealed a significant peak in vocalization activity during the onset of the summer season (Fig. 3). This was followed by a second peak in vocalization activity during early summer ( $\sim 30$ survey days) that corresponded to a peak in activity noted on camera trap data (Fig. 3).
Seasonal activity pattern analysis revealed that the majority of White-winged Flufftail activity took place early- to midsummer, i.e., 0-70 survey days. Peak seasonal activity across all ages was recorded from early- to midsummer, with activity dropping notably from late-summer, i.e., February. When grouped by age, daily activity pattern analysis displayed that although adults and juveniles overlapped greatly in periods of peak activity (Dhat4 = 0.73 ), juveniles were more active over late afternoon/dusk and less active over midday when compared to that of adults (Fig. 4). When grouped by sex, males and females displayed a strong overall overlap coefficient (Dhat $4=0.79$; Fig. 4 ). However, peak daily activity did differ between sexes, with males exhibiting a distinct peak over dawn/sunrise followed by a significant reduction in activity from 10:00 AM, while females displayed a greater peak in activity over late-morning to midday when compared to that of males (Fig. 4). Both sexes displayed high levels of activity over the late afternoon/sunset period. Similarly, seasonal activity patterns also differed between sexes, with males exhibiting higher activity levels early in the season (early to midsummer), followed by lower activity patterns compared to females following midsummer (Fig. 4).

Plumage noted from camera trap data for chicks ( $<1$ week old; Taylor and van Perlo 1998, Taylor et al. 2004) included black downy coloration over the entire body, with some chestnut blotching on the upper tail coverts already present, and whitish coloration at the base of the bill and on the bill tip. From approximately two weeks old, i.e., 10 days after initial sighting of chick/s, faint white spots/blotching was noted on the upper body and upper wings, with pale coloration to the base and tip of bill still present. At approximately four weeks, more prominent chestnut and black barring together with a white terminal edge was evident on the upper tail coverts (Fig. 2). Additionally, conspicuous white coloration on the throat and underparts/belly were visible, along with more prominent white spots (female) on the upper body and upper wings (Fig. 2). Following five to six weeks, signs of postjuvenile molt were noticed, which included incomplete chestnut coloration (mottling) on sides of neck and chest, whitish coloration on belly still present, tail coverts were barred chestnut and black, and the white terminal band on upper tail coverts was no longer present. Additionally, the white base to the bill was no longer present and white bill tip had faded. Upper body and upper wings at this stage either displayed white spots (females) or white streaking (males) as in adults (Taylor and van Perlo 1998), a faint white throat in females, and more chestnut coloration along sides of neck and head in males.

\section{DISCUSSION}

Data related to the breeding, vocalization, activity, and behavior of White-winged Flufftail and other elusive wetland rallids are generally scarce (Eddleman et al. 1994, Taylor 1994, Taylor and van Perlo 1998, Colyn et al. 2017, 2019). Our study confirmed that the use of a survey design including, and combining, both acoustic recorders and camera traps provided a novel and reliable method of drawing from the strengths of both when attempting to survey elusive wetland species. This survey design yielded the largest known dataset of White-winged Flufftail (and three other rallid species) microhabitat use, breeding status and behavior, activity patterns, and intra- and interspecies territoriality in South 
Africa (Allan et al. 2006, Davies et al. 2015, Colyn et al. 2017, 2019). The inclusion of acoustic recorders allowed for the successful confirmation of the vocalization signatures of the species since its description 140 years ago (Ayres 1877). Similarly, camera traps documented the breeding status, success, activity, and facets of microhabitat use by the species that was not captured through acoustic data. This survey design would be applicable to numerous elusive wetland species, enabling the accumulation of data that was unattainable with traditional methods and addressing data deficiencies related to several rallid species globally (BirdLife International 2018).

The use of acoustic recorders, together with camera traps and a tiered data filtering process, proved efficient at elucidating the vocalization signatures of this elusive species. Our study displays that some factors contributing to the call being unidentified todate include vocalization activity being focused early on in the breeding season and not maintained throughout their entire period of occupancy at a site, which has been noted for another small wetland rallid, namely Eastern Black Rail Laterallus jamaicensis jamaicensis (Legare et al. 1999). This reduction in vocalization during occupancy at a site was noted particularly during the incubation period (Legare et al. 1999). Another contributing factor was that the vocalization itself is not very audible amongst other wetland and environmental sounds. The audibility of the call influenced the ability of observers detecting the call beyond $\sim 80 \mathrm{~m}$ at Berga Wetland in our study, but audibility would be more constrained in habitats hosting greater diversity of rallids and other very vocal wetland species. Subsequently, for rapid assessments we recommend that multiple acoustic recorders be used over larger areas and be placed centrally within suitable wetland habitat as opposed to wetland fringes to maximize effective survey area.

The dominant vocalization of White-winged Flufftail identified in our study was unique when compared to other flufftail species in Africa (Appendix 3). Significantly, the vocalization was unlike any of the recorded calls previously attributed to the species (Taylor 1994). However, all of the tape recorded calls attributed to the species, i.e., all "ooping" calls, were made without a bird in view (Taylor 1994) and included other rallid species in the general habitat being surveyed (Taylor 1994). One of the previously attributed ooping calls (Taylor 1994), was identified in our study through acoustic and camera trap data as a variation of the typical Red-chested Flufftail duet. Furthermore, because of these discrepancies, these calls have been retracted and the vocalization has been listed as unknown in a recent ornithological publication (Chittenden et al. 2016). Our study confirms that these calls were incorrectly ascribed to the White-winged Flufftail, and further corroborates the suggestion that they belong to other sympatric wetland species such as Red-chested Flufftail and Grey Crowned Crane (Davies et al. 2015). The confirmation of the call in our study and successful use of this call to elicit call-back responses removes one of the greatest limitations of conservation assessments for the species to-date, namely the unavailability of acoustic surveying as a viable method. The use of passive acoustic monitoring can now be applied as a rapid survey technique across much larger areas than conventional methods (Wrege et al. 2017). In addition to rapid presence/absence surveys, passive acoustic monitoring allows for the assessment of habitat use, population size, and facets of behavior (Wrege et al. 2017).
Our study further highlighted that peak acoustic activity was linked with peak breeding activity on camera images, suggesting that vocalizations were utilized primarily as breeding and territory maintenance cues. The variations in the number of notes and longevity of a call bout may be attributed to the particular social interaction at the time, with more notes and longer bouts being vocalized as active territory defense, and fewer notes and bouts for established pair contact. Interestingly, male activity was greater than that of females around sunrise, which corresponded to peak periods of vocalizations, indicating that males were potentially more acoustically active during these peak breeding periods compared to that of females (Figs. 3 and 4). These two findings could suggest that the efficacy of acoustic surveys as a rapid survey method for this species is linked to breeding events, and in the absence of breeding detection probability might be reduced. However, the use of an acoustic-camera grid would accommodate for this and subsequently maximize detection during both breeding and nonbreeding periods.

The breeding records of White-winged Flufftail documented through our study within South Africa constitute the first undisputable evidence of breeding outside of the Ethiopian Highlands and the Northern Hemisphere (Taylor 1994, Taylor 2005, Evans et al. 2015). Given this was not an isolated event but was confirmed in the following year (2018) again (BirdLife South Africa 2019), confirms that South Africa hosts an additional breeding population to that of the Ethiopian Highlands. Prior to our study, it was thought the species comprised a single breeding population that migrated from the exclusive breeding grounds in Ethiopia to its austral summer nonbreeding range in South Africa (Taylor 2005). Given the presence of juveniles in mid-December in our study and noted age of postjuvenile molt recorded in our study and others (Taylor et al. 2004), as well as the average incubation period of 15 days (Taylor et al. 2004), suggests that breeding (nest building, egg laying, etc.) would have commenced from approximately mid to late October. The primary period of occupation determined by a previous study (Colyn et al. 2019) and further corroborated by our findings, indicates a peak period of occupancy and breeding from late October to late January. The peak presence of White-winged Flufftail on their breeding grounds in Ethiopia has been documented between June and September (Taylor 2005, Allan et al. 2006, Colyn et al. 2020). Subsequently, given confirmed breeding records approximately two months apart at sites on either extremity of the continent ( $\sim 4000 \mathrm{~km}$ between the two study sites), further supports our finding of a separate South African breeding population.

The significance of these findings can directly contribute to the persistence of this critically endangered species. A recent study suggested that all three primary breeding sites in Ethiopia have undergone significant levels $(\sim 95 \%)$ of habitat loss and degradation (Colyn et al. 2020). One of the respective sites known to previously support at least $10-15$ pairs yielded no suitable habitat or presence, while the second site only yielded one pair and less than one hectare of habitat (Colyn et al. 2020). If this species, which currently faces a high extinction risk, is to persist, as many remaining core habitats and sites as possible need to be conserved. In 2008, the White-winged Flufftail International Single Species Action Plan (ISSAP) was published by the Whitewinged Flufftail International Working Group under the auspices of the African Eurasian Waterbird Agreement. The ISSAP refers to knowledge gaps restricting conservation action, with objective 
Avian Conservation and Ecology 15(2): 12 http://www.ace-eco.org/vol15/iss2/art12/

10 of the ISSAP specifically aimed at evaluating the species' breeding biology. Through our findings we can directly influence future research and conservation efforts to save the White-winged Flufftail from extinction.

The identification of a new breeding population in southern Africa provides the potential to locate and conserve additional sites that are critical for the species persistence and ultimate survival. With a confirmed call, we recommend the use of acoustic recording as a rapid means of noninvasively identifying presence at new sites at peak vocalization periods, with a focus on maximizing survey coverage through the use of multiple devices spaced extensively across given sites. Given White-winged Flufftail's sensitivity to human presence within breeding grounds noted in a recent study (Howes-Whitecross et al. 2020), coupled with their high extinction risk (Colyn et al. 2020), threat status (Evans et al. 2015), and habitat degradation (Colyn et al. 2020), we do not recommend the use of call-broadcast surveys or any invasive form of sampling, i.e., walked transects, flushing, etc., going forward. Passive acoustic monitoring can provide more robust datasets and assess a range of ecological facets noninvasively (Wrege et al. 2017), while yielding presence records more rapidly as was noted in our study, i.e., vs call-broadcasts. Furthermore, surrounding recorders with intensive sampling grids of camera traps as used in this study could provide insight into the importance of the site in terms of breeding, population structure (sex and age ratios), and spatio-temporal patterns of habitat use (particularly during nonvocal periods).

Responses to this article can be read online at: http://www.ace-eco.org/issues/responses.php/1681

\section{Acknowledgments:}

We would like to acknowledge the Department of Environmental Affairs (now Department of Environment, Forestry and Fisheries), Airports Company South Africa, and the Ingula Partnership, particularly Eskom and the Middelpunt Wetland Trust (Malcolm Drummond), for their support and involvement in the project. Thanks to Ekapa for providing financial support for the BirdLife South Africa Ekapa Fellow of Bird Conservation post of RB Colyn. Thanks to the Ethiopian Wildlife \& Natural History Society (EWNHS), Bruktawit Abdu, and Samson Zelleke for their assistance and support, as well as the local Site Support group based at Berga Wetland, Ethiopia. Similarly, thanks to Carina Coetzer, Melissa Whitecross, and Caroline Howes for their assistance during various facets of field work in South Africa and Ethiopia. Our thanks to Greg Davies and Faansie Peacock for their assistance with the first vetting of the vocalizations recorded. This project received ethics clearance from the BirdLife South Africa Ethics Committee to carry out behavioral observations on this critically endangered rallid $(2016 / 01 / \mathrm{Al} ; 2016 / 02 / \mathrm{Al})$. The data that support the findings of this study are openly available in figshare at https:/lfigshare.com, reference number 70232.

\section{LITERATURE CITED}

Allan, D. G., A. M. McInnes, and M. Wondafrash. 2006. Whitewinged Flufftail Sarothrura ayresi in Ethiopia: notes on the habitat, densities, morphometrics, nests and eggs and associated waterbirds. Bulletin of African Bird Club 13:25-36.

Ayres, T. 1877. Additional notes on the ornithology of the Republic of Transvaal. Ibis 19:339-354. https://doi.org/10.1111/ j.1474-919X.1877.tb06572.x

Baylis, T., F. W. van Gessel, and S. J. S. Debus. 2015. Some vocalisations of the Grey Falcon Falco hypoleucos. Corella 39:73-76.

Bibby, C., M. Jones, and S. Marsden. 1998. Expedition field techniques: bird surveys. Royal Geographical Society, London, UK.

BirdLife International. 2018. White-winged Flufftail: Sarothrura ayresi. IUCN Red List of threatened species e.T22692245A130479784. https://doi.org/10.2305/iucn.uk.2018-2.rlts.t22692245a130479784. en

BirdLife South Africa. 2019. White-winged Flufftail surveys in South Africa. BirdLife South Africa, Johannesburg, South Africa.

Bogner, H. E., and G. A. Baldassarre. 2002. The effectiveness of call-response surveys for detecting Least Bitterns. Journal of Wildlife Management 66:976-984. https://doi.org/10.2307/3802930

Brandes, T. S. 2008. Automated sound recordings and analysis techniques for bird surveys and conservation. Bird Conservation International 18:163-173. https://doi.org/10.1017/S0959270908000415

Browning, E., R. Gibb, P. Glover-Kapfer, and K. E. Jones. 2017. Passive acoustic monitoring in ecology and conservation. WWF conservation technology series. WWF-UK, Woking, UK. https:// doi.org/10.13140/RG.2.2.18158.46409

Catchpole, C. K., and P. J. B. Slater. 2008. Birdsong: biological themes and variations. Cambridge University Press, Cambridge, UK. https://doi.org/10.1017/CBO9780511754791

Chittenden, H., G. Davies, and I. Weiersbye. 2016. Roberts bird guide. Second edition. The John Voelcker Bird Book Fund, Cape Town, South Africa.

Colyn, R. C., A. M. Campbell, and H. A. Smit-Robinson. 2017. The application of camera trapping to assess rallidae species richness within palustrine wetland habitat in South Africa. Ostrich: Journal of African Ornithology 88:235-245. https://doi. org/10.2989/00306525.2017.1292562

Colyn, R. B., A. M. Campbell, and H. A. Smit-Robinson. 2019. Camera-trapping successfully and non-invasively reveals the presence, activity and habitat choice of the critically endangered White-winged Flufftail Sarothrura ayresi in a South African highaltitude wetland. Bird Conservation International 29:463-478. https://doi:10.1017/S0959270918000400

Colyn, R. B., M. A. Howes-Whitecross, C. Howes, and H. A. Smit-Robinson. 2020. Restricted breeding habitat of the critically endangered White-winged Flufftail in Ethiopia and its conservation implications. Ostrich: Journal of African Ornithology. https://doi.org/10.2989/00306525.2020.1737259

Conway, C. J. 2011. Standardized North American marsh bird monitoring protocol. Waterbirds 34:319-346. https://doi. org/10.1675/063.034.0307 
Avian Conservation and Ecology 15(2): 12 http://www.ace-eco.org/vol15/iss2/art12/

Conway, C. J., and J. P. Gibbs. 2005. Effectiveness of callbroadcast surveys for monitoring marsh birds. Auk 122:26-35. https://doi.org/10.1093/auk/122.1.26

Davies, G. B. P., H. A. Smit-Robinson, I. M. M. Drummond, B. Gardner, S. Rautenbach, D. van Stuyvenberg, C. Nattrass, M. Pretorius, D. W. Pietersen, and C. T. Symes. 2015. Recent records of the White-winged Flufftail Sarothrura ayresi (Aves, Sarothruridae) in South Africa, including details of a survey of high-altitude wetlands in 2013-14. Durban Natural Science Museum Novitates 37:62-75.

Eddleman, W. R., R. E. Flores, and M. Legare. 1994. Black Rail (Laterallus jamaicensis), version 2.0. In A. Poole and F. B. Gill, editors. The birds of North America. Cornell Lab of Ornithology, Ithaca, New York, USA. https://doi.org/10.2173/bna.123

Evans, S. W., H. A. Smit-Robinson, and W. Tarboton. 2015. White-winged Flufftail. Pages 41-43 in M. R. Taylor, F. Peacock, R. M. Wanless, editors. The 2015 Eskom red data book of birds of South Africa, Lesotho and Swaziland. BirdLife South Africa, Johannesburg, South Africa.

Fletcher, R. J., J. A. Dhundale, and T. F. Dean. 2000. Estimating non-breeding bird abundance in prairies: a comparison of two survey techniques. Journal of Field Ornithology 71:321-329. https://doi.org/10.1648/0273-8570-71.2.321

Garcia, J. C., G. C. Gibb, and S. A. Trewick. 2014. Deep global evolutionary radiation in birds: diversification and trait evolution in the cosmopolitan bird family Rallidae. Molecular Phylogenetics and Evolution 81:96-108. https://doi.org/10.1016/j.ympev.2014.09.008

Gibbon, G. 2012. Roberts VIImultimedia birds of Southern Africa. Southern Africa Birding CC, Westville, South Africa.

Hand, C. E., E. Znidersic, and A. K. Tegeler. 2019. First documentation of Eastern Black Rails (Laterallus jamaicensis jamaicensis) breeding in South Carolina, USA in more than a century. Waterbirds 42:237-241. https://doi.org/10.1675/063.042.0212

Hill, S. D. 2011. The vocalisation of tui (Prosthemadera novaeseelandiae). Thesis. Massey University, Auckland, New Zealand.

Hill, S. D. 2018. A rare vocalisation from an adult female tui (Prosthemadera novaeseelandiae). Notornis 65:237-238.

Howes-Whitecross, M. A., C. Howes, R. B. Colyn, and H. A. Smit-Robinson. 2020. Challenges in nest monitoring of Whitewinged Flufftails Sarothrura ayersi in Ethiopia. Ostrich: Journal of African Ornithology 1:1-5. https://doi.org/10.2989/00306525.2020.1794996

Kirby, J. S., A. J. Stattersfield, S. H. M. Butchart, M. I. Evans, R. F. A. Grimmett, V. R. Jones, J. O'Sullivan, G. M. Tucker, and I. Newton. 2008. Key conservation issues for migratory land- and waterbird species on the world's major flyways. Bird Conservation International 18:S49-S73. https://doi.org/10.1017/S0959270908000439

Legare, M. L., W. R. Eddleman, P. A. Buckley, and C. Kelly. 1999. The effectiveness of tape playback in estimating Black Rail density. Journal of Wildlife Management 63:116-125. https://doi. org/10.2307/3802492
Linkie, M., and M. S. Rideout. 2011. Assessing tiger-prey interactions in Sumatran rainforests. Journal of Zoology 284:224-229. https://doi.org/10.1111/j.1469-7998.2011.00801.x

Lor, S., and R. A. Malecki. 2002. Call-response surveys to monitor marsh bird population trends. Wildlife Society Bulletin 30:1195-1201.

Mendelsohn, J. M., J. C. Sinclair, and W. R. Tarboton. 1983. Flushing flufftail out of vleis. Bokmakierie 35:9-11.

Meredith, M., and M. Ridout. 2017. Overlap: estimates of coefficient of overlapping for animal activity patterns. [online] URL: https://cran.r-project.org/web/packages/overlap/overlap. pdf

Niedballa, J., R. Sollmann, A. Courtiol, and A. Wilting. 2016. camtrapR: an $\mathrm{R}$ package for efficient camera trap data management. Methods in Ecology and Evolution 7:1457-1462. https://doi.org/10.1111/2041-210X.12600

Norambuena, H. V., and A. Muñoz-Pedreros. 2017. Detection and vocalisations of three owl species (Strigiformes) in temperate rainforests of southern Chile. New Zealand Journal of Zoology 45:121-135. https://doi.org/10.1080/03014223.2017.1395749

R Development Core Team. 2017. R: A language and environment for statistical computing. R Foundation for Statistical Computing, Vienna, Austria. [online] URL: https://www.r-project.org/

Ramsar Convention on Wetlands. 2018. Global wetland outlook: state of the world's wetlands and their services to people. Ramsar Convention Secretariat, Gland, Switzerland.

Rideout, M. S., and M. Linkie. 2009. Estimating overlap of daily activity patterns from camera trap data. Journal of Agricultural, Biological, and Environmental Statistics 14:322-327. https://doi. org/10.1198/jabes.2009.08038

Rovero, F., F. Zimmermann, D. Berzi, and P. Meek. 2013. "Which camera trap type and how many do I need?" A review of camera features and study designs for a range of wildlife research applications. Hystrix 24:148-156.

Sidie-Slettedahl, A. M., K. C. Jensen, R. R. Johnson, T. W. Arnold, J. E. Austin, and J. D. Stafford. 2015. Evaluation of autonomous recording units for detecting 3 species of secretive marsh birds. Wildlife Society Bulletin 39:626-634. https://doi. org/10.1002/wsb.569

Sueur, J., T. Aubin, C. Simonis, L. Lellouch, E. C. Brown, M. Depraetere, C. Desjonqueres, F. Fabianek, A. Gasc, E Kasten, et al. 2019. Seewave: sound analysis and synthesis. https://cran.rproject.org/web/packages/seewave/index.html

Taylor, P. B. 1987. A field study of the Spotted Crake Porzana porzana at Ndola, Zambia. Ostrich: Journal of African Ornithology 58:107-117. https://doi.org/10.1080/00306525.1987.9633681

Taylor, P. B. 1994. The biology, ecology and conservation of four Flufftail species, Sarothrura (Aves: Rallidae). Dissertation. University of KwaZulu-Natal, Pietermaritzburg, South Africa.

Taylor P. B. 2005. White-winged Flufftail. Pages 321-322 in P. A. R. Hockey, W. R. J. Dean, and P. G. Ryan, editors. Roberts birds of Southern Africa, 7th edition. The Trustees of the John Voelcker Bird Book Fund, Cape Town, South Africa. 
Taylor, P. B., and B. van Perlo. 1998. Rails: a guide to the rails, crakes, galinules and coots of the world. Pica Press, Sussex, UK.

Taylor, P. B., M. Wondafrash, and Y. Demeke. 2004. The nest, eggs and chicks of the White-winged Flufftail Sarothrura ayresi. Bulletin of the British Ornithologists' Club 124:233-239.

Turcotte, Y., and A. Desrochers. 2002. Playbacks of mobbing calls of Black-capped Chickadees help estimate the abundance of forest birds in winter. Journal of Field Ornithology 73:303-307. https://doi.org/10.1648/0273-8570-73.3.303

Wrege, P. H., E. D. Rowland, S. Keen, and Y. Shiu. 2017. Acoustic monitoring for conservation in tropical forests: examples from forest elephants. Methods in Ecology and Evolution 8:1292-1301. https://doi.org/10.1111/2041-210X.12730

Znidersic, E. 2017. Camera traps are an effective tool for monitoring Lewin's Rail (Lewinia pectoralis brachipus). Waterbirds 40:417-422. https://doi.org/10.1675/063.040.0414

Znidersic, E., T. Flores, I. Macrae, J. C. Z. Woinarski, and D. M. Watson. 2019. Camera trapping and transect counts yield complementary insights into an endangered island endemic rail. Pacific Conservation Biology 25:394-402. https://doi:10.1071/ PC18067 
Appendix 1. White-winged Flufftail (Sarothrura ayresi) calls were often repeated rapidly, including (a) sequence of five-note "chit" calls repeated six times over 8.5 seconds and (b) sequence of interchanged 3-note and 4-note "chit" calls. Amplitude (dB) is displayed as the default seewave $10 \log 10$ (power ratio) scale.
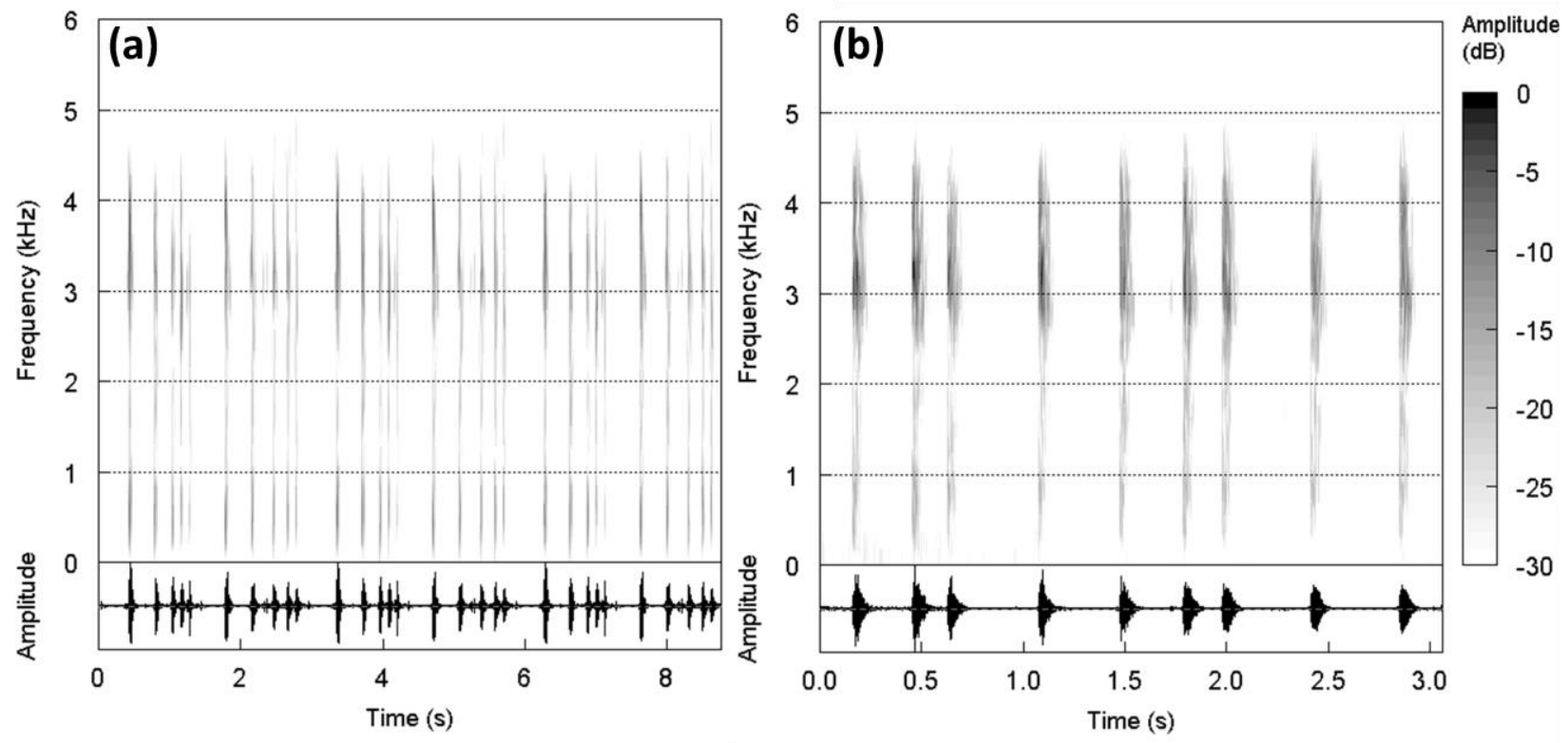
Appendix 2. Dominant vocalizations (spectrograms) of rallid species recorded at the study sites in South Africa and Ethiopia: (a) Africa Rail (Rallus caerulescens), (b) Black Crake (Amaurornis flavirostra) territorial call, (c) Black Crake chittering, d) Red-chested Flufftail (Sarothrura rufa) territorial call, (e) Red-chested Flufftail "ooping" call, (f) Red-chested Flufftail "ooping" duet, (g) Rouget's Rail (Rougetius rougetii; exclusively recorded in Ethiopia), and (h) White-winged Flufftail (Sarothrura ayresi). Where possible, spectrograms were constrained to 6 seconds to promote visual comparability.
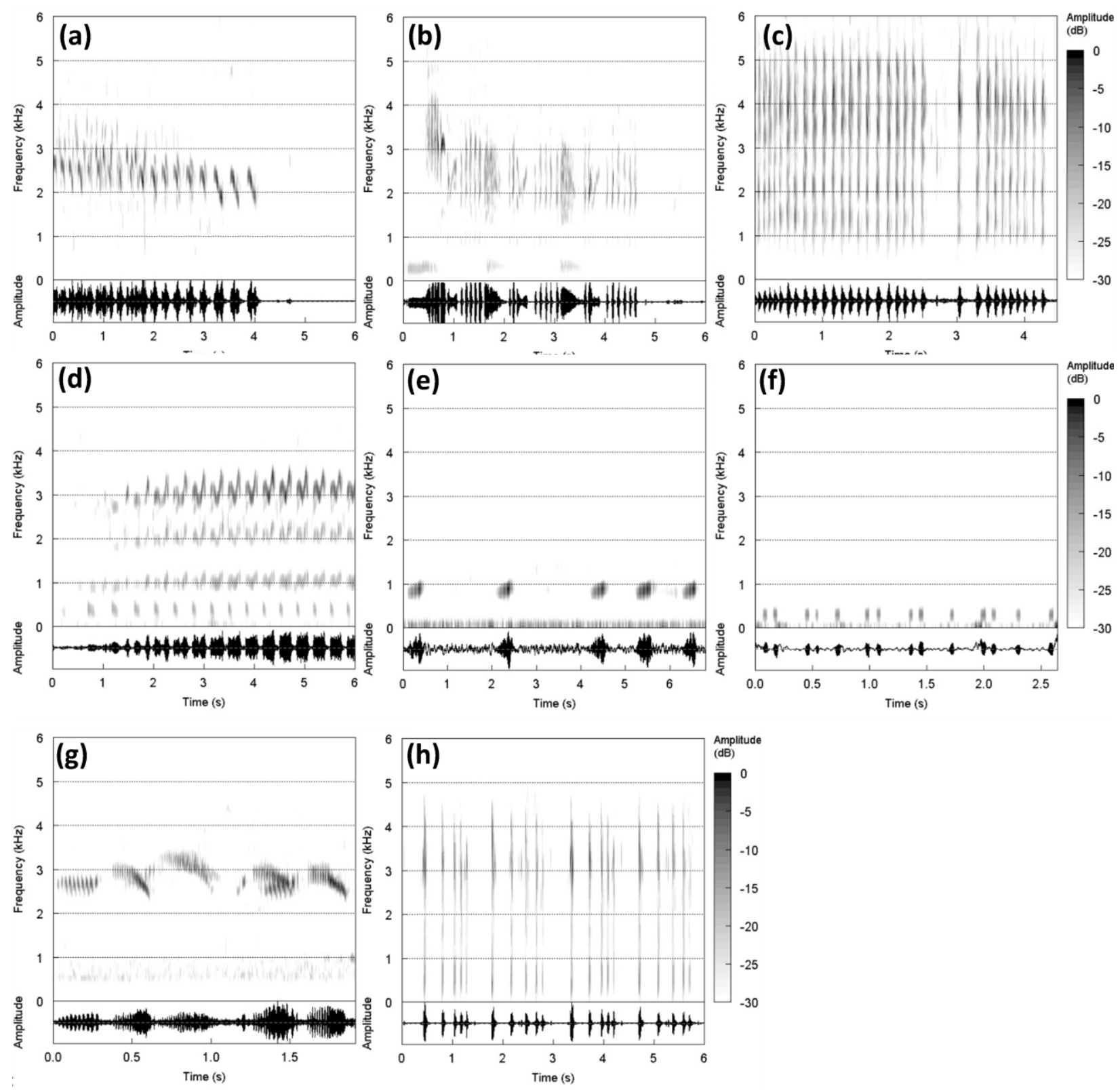
Appendix 3. Comparative analysis of White-winged Flufftail (Sarothrura ayresi) vocalizations recorded in our study displayed that it was acoustically unique when compared to vocalizations (spectrograms) of other Flufftail species (https://www.xeno-canto.org) in Africa: (a) Whitespotted Flufftail (Sarothrura pulchra), (b) Streaky-breasted Flufftail (Sarothrura boehmi), (c) Slender-billed Flufftail (Sarothrura watersi), (d) Striped Flufftail (Sarothrura affinis), (e) Madagascar Flufftail (Sarothrura insularis), (f) Red-chested Flufftail (Sarothrura rufa), (g) Chestnut-headed Flufftail (Sarothrura lugens), (h) Buff-spotted Flufftail (Sarothrura elegans), and (i) White-winged Flufftail. Where possible, spectrograms were constrained to 6 seconds to promote visual comparability.
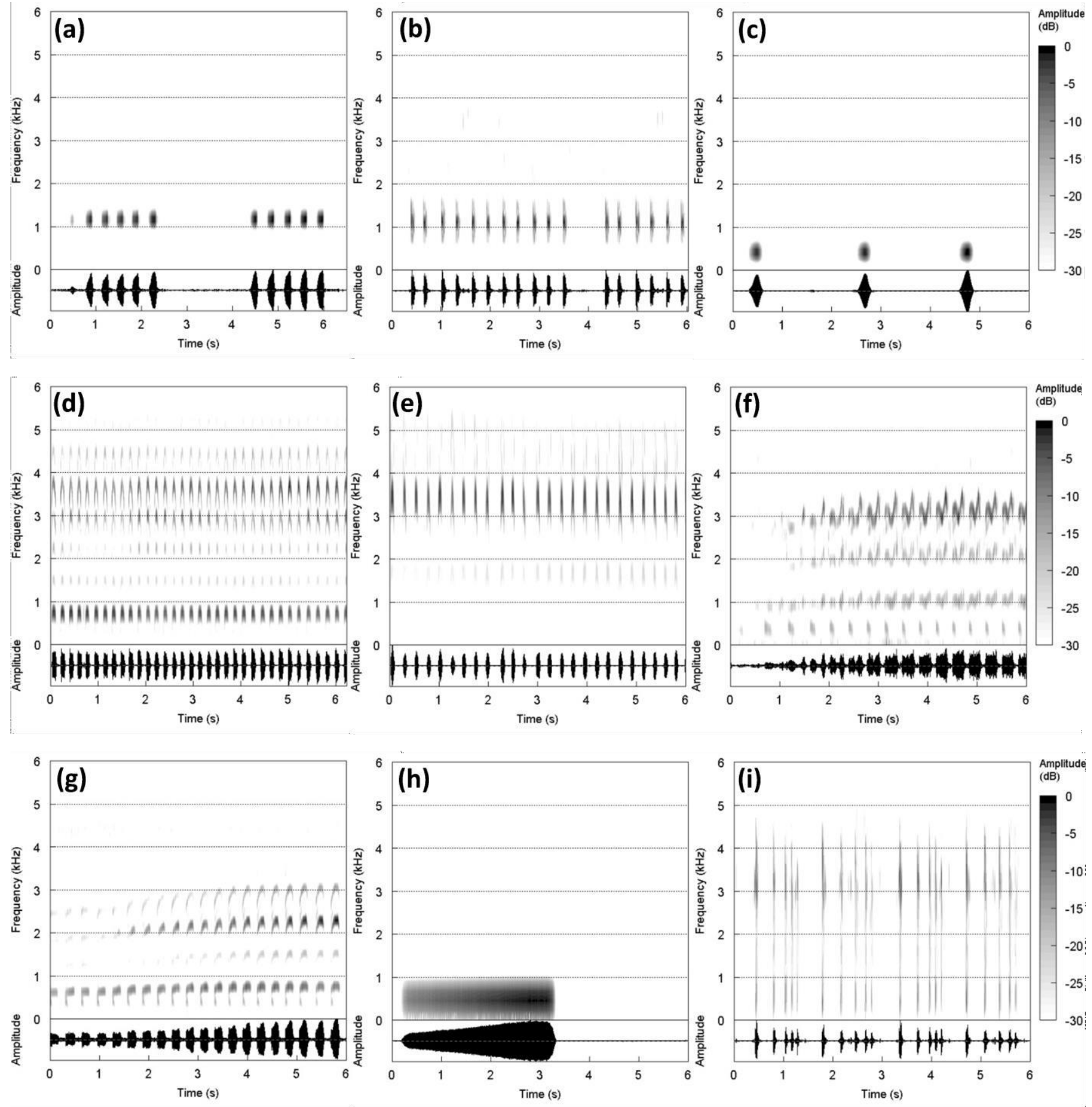